(c) American Dairy Science Association, 2004.

\title{
The Energy Content of Wet Corn Distillers Grains for Lactating Dairy Cows*
}

\author{
C. P. Birkelo, ${ }^{1,} †$ M. J. Brouk, ${ }^{2} \neq$ and D. J. Schingoethe ${ }^{2}$ \\ ${ }^{1}$ Department of Animal and Range Sciences and \\ ${ }^{2}$ Department of Dairy Science, \\ South Dakota State University, Brookings 57007-0647
}

\section{ABSTRACT}

Forty-five energy balances were completed with 12 multiparous, lactating Holstein cows in a study designed to determine the energy content of wet corn distillers grains. Treatments were applied in a repeated switchback design and consisted of total mixed diets containing $31.4 \%$ corn silage, $18.4 \%$ alfalfa hay, and either $30.7 \%$ rolled corn and $16.7 \%$ soybean meal or $17.0 \%$ rolled corn and $31.2 \%$ wet corn distillers grains (dry matter basis). Replacement of corn and soybean meal with wet corn distillers grains reduced dry matter intake $10.9 \%$ but did not affect milk production. Neither digestible nor metabolizable energy were affected by diet composition. Heat and milk energy output did not differ by diet, but body energy retained was $2.8 \mathrm{Mcal} /$ $\mathrm{d}$ less in cows fed the wet corn distillers grains diet. Multiple regression estimates of maintenance metabolizable energy requirement and partial efficiencies of metabolizable energy used for lactation and body energy deposition did not differ by diet. Pooled estimates were $136.2,0.66$, and 0.85 , kcal of metabolizable energy/ body weight ${ }^{0.75}$ per day, respectively. Calculated by difference, wet corn distillers grains was estimated to contain $4.09,3.36$, and $2.27 \mathrm{Mcal} / \mathrm{kg}$ of dry matter as digestible, metabolizable, and lactational net energy, respectively. These energy estimates were 7 to $11 \%$ and 10 to $15 \%$, respectively, greater than those reported for dried corn distillers grains by the 1989 and 2001 dairy NRC publications.

(Key words: wet corn distillers grains, lactation, energy metabolism)

Abbreviation key: $\mathbf{C D G}=$ corn distillers grains, $\mathbf{D E}=$ digestible energy, $\mathbf{E E}=$ ether extract, $\mathbf{G E}=$ gross en-

Received September 10, 2003.

Accepted December 19, 2003.

Corresponding author: D. J. Schingoethe; email: david schingoethe@sdstate.edu

*Published with the approval of the Director of the South Dakota Agric. Exp. Sta. as Publication Number 2065 of the Journal Series. $\dagger$ Present address: 901 Telles Lane, Woodland Park, CO 80862.

$\ddagger$ Present address: Dept. of Animal Sciences and Industry, Kansas State University, Manhattan, KS 66506. ergy, $\mathbf{M E}=$ metabolizable energy, $\mathbf{M E}_{\mathbf{m}}=$ metabolizable energy for maintenance.

\section{INTRODUCTION}

Distillers grains is a coproduct of ethanol production, with corn being the main feedstock used for ethanol production in the Midwestern region of the United States. Nutrient composition of the resulting distillers grains primarily reflects that of corn after starch removal. Corn distillers grains (CDG) is often fed wet to avoid drying costs. Its use as a supplemental protein source for ruminant livestock has been extensively researched by Schingoethe (2001). However, less is known about its effects on diet energy content. Estimates of CDG energy content based on growing beef cattle performance have ranged from 83 to $169 \%$ that of corn grain (Larson et al., 1993; Klopfenstein, 2001). Estimates based on lactating dairy cow performance have been almost as variable (Palmquist and Conrad, 1982; Schingoethe et al., 1983). Some of the discrepancies occur because recent improved processing techniques likely result in more efficient removal of starch from the corn, which results in CDG containing more protein, fat, and fiber than CDG available prior to 1990. Effects of wet CDG on diet energy partitioning of lactating dairy cows have not been previously reported. Field observations indicate that CDG may contain more energy than reported in the dairy NRC reports (1989, 2001).

The objective of this study was to investigate the effect of including wet CDG in diets at the expense of corn and soybean meal on energy partitioning by lactating dairy cows using total collection and calorimetric techniques. Lactation response data from this trial were previously reported (Schingoethe et al., 1999).

\section{MATERIALS AND METHODS}

Twelve multiparous Holstein cows (BW $584 \mathrm{~kg}$ ) averaging 23 DIM at the start of the experiment were utilized in a repeated switchback design (Cochran and 
Table 1. Composition and analyses for control (C) and wet corn distillers grains (CDG) diets.

\begin{tabular}{|c|c|c|}
\hline & \multicolumn{2}{|c|}{ Diet } \\
\hline & $\mathrm{C}$ & Wet CDG \\
\hline & $\longrightarrow$ & 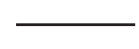 \\
\hline Corn silage & 31.4 & 30.9 \\
\hline Alfalfa hay & 18.4 & 18.5 \\
\hline Wet $\mathrm{CDG}^{\mathrm{1}}$ & - & 31.2 \\
\hline Rolled corn & 30.7 & 17.0 \\
\hline Soybean meal, $44 \%$ CP & 16.7 & - \\
\hline Calcium carbonate & 1.39 & 1.35 \\
\hline Dicalcium phosphate & 0.87 & 0.56 \\
\hline Trace mineralized salt ${ }^{2}$ & 0.20 & 0.19 \\
\hline $\mathrm{MgO}$ & 0.13 & 0.12 \\
\hline Vitamin premix ${ }^{3}$ & 0.10 & 0.10 \\
\hline Vitamin premix ${ }^{4}$ & 0.06 & 0.06 \\
\hline \multicolumn{3}{|l|}{ Analysis } \\
\hline $\mathrm{DM}, \%$ & 68.5 & 47.0 \\
\hline $\mathrm{CP}$ & 18.0 & 21.0 \\
\hline Ether extract (EE) & 3.1 & 5.1 \\
\hline NDF & 28.3 & 42.9 \\
\hline $\mathrm{ADF}$ & 16.9 & 21.3 \\
\hline $\mathrm{Ca}$ & 1.13 & 1.04 \\
\hline $\mathrm{P}$ & 0.48 & 0.49 \\
\hline $\mathrm{Mg}$ & 0.29 & 0.27 \\
\hline Ash & 7.1 & 5.9 \\
\hline
\end{tabular}

${ }^{1}$ Wet corn distillers grain was $30.9 \pm 1.1 \%$ DM. CP, EE, NDF, and $\mathrm{ADF}$ contents were $39.5 \pm 1.4,8.5 \pm 1.1,58.1 \pm 6.0$, and $23.4 \pm 2.1 \%$ of DM, respectively. Gross energy content was $5.37 \mathrm{Mcal} / \mathrm{kg} \mathrm{DM}$.

${ }^{2}$ Contained NaCl, 93 to $98 \%$; $\mathrm{Zn}, 0.35 \% ; \mathrm{Mn}, 0.28 \%$; Fe, $0.175 \%$; $\mathrm{Cu}, 0.035 \%$; I, 0.007\%; Co, 0.007 .

${ }^{3}$ Contained $4,400,000$ IU of vitamin A, 880,000 IU of vitamin D, and $400 \mathrm{IU}$ of vitamin $\mathrm{E}$ per $\mathrm{kg}$.

${ }^{4}$ Contained 44,000 IU of vitamin E per kg.

Cox, 1957) to evaluate diets with or without wet CDG. Diet composition and analyses are presented in Table 1. Compositions differed in that the test diet contained wet CDG at $31.2 \%$ of DM in place of all of the soybean meal and almost one-half of the rolled corn contained in the control diet. The alfalfa hay and corn silage fed throughout the study were from a single source. The wet CDG was acquired weekly from a commercial ethanol plant and stored at ambient temperature in steel drums. Diets were fed once daily. The experiment was conducted from January until June and had minimal environmental temperature impact on feed stability. All procedures for this study were conducted under approval of the South Dakota State University Animal Care and Use Committee.

The cows were blocked into 3 groups of 4 cows each according to calving dates. Two cows within each block were given initial assignments to diets with or without wet CDG. The cows were switched between treatments during 4 successive adaptation/collection periods. Each period consisted of $28 \mathrm{~d}$ of ad libitum diet adaptation, $7 \mathrm{~d}$ of restricted intake (95\% of ad libitum to minimize or eliminate the need to account for unconsumed feed) and adaptation to facilities and procedures, and $6 \mathrm{~d}$ of collections at restricted intake. Average days postpartum for collection periods 1 through 4 were 55, 97, 139, and 179 , respectively. The cows were less than $90 \mathrm{~d}$ pregnant at the conclusion of the study. The cows were milked twice per day at 0500 and $1600 \mathrm{~h}$.

Individual feeds were sampled daily at the time of feeding and stored frozen at $-20^{\circ} \mathrm{C}$ for later compositing by period and chemical analysis. Feces were also collected daily and mixed prior to subsampling. Urine was collected by catheter (Foley, size 24 French, 75 cc balloon; Bard Urological Division, Covington, GA) into 20$\mathrm{L}$ plastic containers acidified with $50 \mathrm{~mL}$ of concentrated $\mathrm{HCl}$. Aliquots of orts (4\%), feces (4\%), and urine $(2 \%)$ were composited by period and frozen at $-20^{\circ} \mathrm{C}$. Subsequent analyses for CP, ether extract (EE), and ash were performed according to procedures of AOAC (1990). Determination of NDF and ADF were as described by Van Soest et al. (1991) and Robertson and Van Soest (1981), respectively. Milk samples were taken at each milking during the collection period. Protein, fat, and lactose of milk samples were determined by midinfrared spectrophotometry (Multispec; Foss Food Technology Corp., Eden Prairie, MN) according to AOAC (1990). Gross energy (GE) of samples was determined with an adiabatic bomb calorimeter (Parr Instrument Co., Inc., Moline, IL). Milk and urine samples were first lyophilized before bomb calorimetry.

Heat production was determined for 2 consecutive 23-h intervals during each collection period by indirect respiration calorimetry. The system was comprised of 4 modified hood (head box) calorimeters as described by Shuey et al. (1993). Heat production was calculated from oxygen consumption, and carbon dioxide and methane production with correction for urinary $\mathrm{N}$ loss according to Brouwer (1965). The amount of methane formed was multiplied by a constant $(9.45 \mathrm{kcal} / \mathrm{L})$ to estimate the amount of energy represented in the formation of gaseous products (Brouwer, 1965; heat production $[\mathrm{kcal}]=3.866 \times \mathrm{O}_{2}[\mathrm{~L}]+\mathrm{CO}_{2}[\mathrm{~L}]-0.518 \times \mathrm{CH}_{4}[\mathrm{~L}]$ $-1.431 \times \mathrm{N}^{2}$ [grams]). Energy balance was adjusted for excess $\mathrm{N}$ intake according to Moe et al. (1970) and averaged 1.5 and $2.4 \%$ of metabolizable energy (ME) intake for control and wet CDG diets, respectively.

Data were analyzed statistically using the GLM procedures of SAS (1988). The original model included the effects of diet, period, cow, and diet $\times$ period. The interaction never achieved significance $(P>0.20)$ and was subsequently dropped from the model. Least squares means are reported. The step-wise multiple regression technique used to partition ME was performed using the REG procedures of SAS (1988). The model initially included $\mathrm{BW}^{0.75}$, body energy retained, and milk energy. Subsequent modification is discussed later. 
Table 2. Performance data for lactating cows fed control (C) and wet corn distillers grains (CDG) diets. ${ }^{1}$

\begin{tabular}{|c|c|c|c|}
\hline \multirow[b]{2}{*}{ Item } & \multicolumn{2}{|c|}{ Diets } & \multirow[b]{2}{*}{ SE } \\
\hline & $\mathrm{C}$ & Wet CDG & \\
\hline $\mathrm{BW}, \mathrm{kg}^{2}$ & 589 & 575 & 3.3 \\
\hline DMI, $\mathrm{kg} / \mathrm{d}^{2,4}$ & 22.1 & 19.7 & 0.43 \\
\hline Milk yield, kg/d & 30.7 & 30.8 & 0.66 \\
\hline Milk fat, $\%^{3}$ & 3.60 & 3.85 & 0.09 \\
\hline Milk protein, $\%^{2}$ & 3.06 & 2.84 & 0.02 \\
\hline Milk lactose, $\%$ & 4.83 & 4.85 & 0.03 \\
\hline Somatic cells, $10^{5} / \mathrm{mL}$ & 2.80 & 2.30 & 0.73 \\
\hline
\end{tabular}

${ }^{1}$ Least square means.

${ }^{2}$ Means differ, $P<0.01$.

${ }^{3}$ Means differ, $P<0.10$.

${ }^{4} 95 \%$ of ad libitum.

\section{RESULTS AND DISCUSSION}

Inability to use a single batch of wet CDG resulted in some variability in nutrient concentration. Coefficients of variation for $\mathrm{DM}, \mathrm{CP}, \mathrm{NDF}$, and $\mathrm{EE}$ were 3.5, $3.5,10.3$, and $12.7 \%$, respectively (Table 1 ). Similar nutrient variability of wet DG has been previously noted (Dolge, 1988). The diets were formulated on a DM basis to contain $18 \%$ CP. However, higher than expected CP content of the wet CDG resulted in $21 \%$ $\mathrm{CP}$ in the test diet. Approximately $21 \%$ of the $\mathrm{CP}$ in wet CDG was acid detergent insoluble. Neutral detergent fiber and GE contents of the wet CDG diet were 52 and $6 \%$ greater than that of the control diet, reflecting the high fiber and fat contents of the wet CDG.

Energy balances (45 of 48) were completed. Loss of data was due to health problems unrelated to the experimental treatments. Replacement of corn and soybean meal with wet CDG decreased collection period DMI (set at $95 \%$ of ad libitum) by $10.9 \%$ (Table $2 ; P<0.01$ ). Reduction in DMI has been associated with diet DM contents below 60\% (Lahr et al., 1983). The wet CDG diet DM was $47.0 \%$ compared with $68.5 \%$ for the control diet and may be responsible for at least some of the observed intake difference. However, Schingoethe et al. (1983) reported no such DMI reduction when wet CDG was included at $22 \%$ of diet DM in 51\% DM diets. Milk output and percentage of lactose were not affected by $\operatorname{diet}(P>0.20)$. Milk fat percentage increased $(P<0.10)$ and milk protein percentage decreased $(P<0.01)$ by feeding wet CDG. Similar effects on milk composition have been previously reported when adding fat to lactation diets (Palmquist and Jenkins, 1980).

Apparent digestibilities of $\mathrm{CP}, \mathrm{NDF}, \mathrm{ADF}$, and $\mathrm{EE}$ were increased $(P<0.01)$ with the inclusion of wet CDG in the diet (Table 3). This, together with lack of difference in DM digestibility, suggests poorer utilization of residual solubles in the wet CDG diet. This may,
Table 3. Apparent digestibilities of control (C) and wet corn distillers grains (CDG) diets by lactating cows. ${ }^{1}$

\begin{tabular}{llcl}
\hline & \multicolumn{2}{c}{ Diets } & \\
\cline { 2 - 3 } Item & $\mathrm{C}$ & Wet CDG & $\mathrm{SE}$ \\
\cline { 2 - 3 }$(\%)$ & & \\
\cline { 2 - 3 } $\mathrm{DM}$ & 67.2 & 65.8 & 0.55 \\
$\mathrm{CP}^{2}$ & 68.4 & 73.4 & 0.77 \\
$\mathrm{NDF}^{2}$ & 49.2 & 60.6 & 0.88 \\
$\mathrm{ADF}^{2}$ & 46.4 & 57.7 & 0.86 \\
Ether extract $^{2}$ & 67.6 & 78.4 & 1.48 \\
\hline${ }^{1}$ Least square means. & & \\
\multicolumn{2}{c}{${ }^{2}$ Means differ, $P<0.01}$. & &
\end{tabular}

in part, be an artefact of the greater than usual CP content of the wet CDG used in this study (39.5\% vs. more normal $\sim 34 \%$ of DM). Considerable amounts of $\mathrm{N}$ were bound to the NDF and ADF fractions of the wet CDG (Table 4), equivalent to nearly 40 and $21 \%$ of its $\mathrm{CP}$ content, respectively; possibly the result of ammonia addition to the mash during fermentation. Such a large nonprotein $\mathrm{N}$ fraction would cause underestimation of solubles content, and thus digestibility because both are calculated by difference (Schingoethe et al., 1999.

Gross energy intake was reduced less than DMI (5.5\%, $P<0.10)$, reflecting the effect of greater GE content of wet CDG compared with corn and soybean meal (Table 5). Numerically lower, but statistically nonsignificant $(P>0.20)$, fecal energy losses for the wet CDG diet resulted in similar energy digestibilities $(P<0.20)$ despite intake differences.

As a percentage of GE intake, methane production decreased $14.4 \%(P<0.01)$ and urinary energy loss increased $16.0 \%(P<0.01)$ by the inclusion of wet CDG in the diet. Hindgut methane emissions that would not be captured by the head box system are reportedly small ( 1 to $2 \%$ of total tract production) and was assumed in this study to be of little consequence to heat production calculations (Murray et al., 1976). Similar changes in

Table 4. N partitioning by lactating cows fed control (C) or wet corn distillers grains (CDG) diets. ${ }^{1}$

\begin{tabular}{lrrr}
\hline & \multicolumn{2}{c}{ Diet } & \\
\cline { 2 - 3 } Item & $\mathrm{C}$ & $\mathrm{CDG}$ & $\mathrm{SE}$ \\
\cline { 2 - 3 } & & $\mathrm{g} / \mathrm{d})$ & \\
\cline { 2 - 3 } Intake N & 606 & 635 & 16.2 \\
Fecal N $^{3}$ & 191 & 171 & 4.5 \\
Urine N $^{3}$ & 245 & 295 & 8.3 \\
Milk N $^{2}$ & 147 & 137 & 11.0 \\
$\mathrm{~N}$ balance & 24 & 31 & \\
\hline${ }^{1}$ Least square means. & & \\
${ }^{2}$ Means differ, $P<0.05$. & & \\
${ }^{3}$ Means differ, $P<0.01$. & &
\end{tabular}


Table 5. Energy partitioning by lactating cows fed control (C) or wet corn distillers grains (CDG) diets. ${ }^{1}$

\begin{tabular}{|c|c|c|c|}
\hline \multirow[b]{2}{*}{ Item } & \multicolumn{2}{|c|}{ Diets } & \multirow[b]{2}{*}{ SE } \\
\hline & $\mathrm{C}$ & Wet CDG & \\
\hline & \multicolumn{2}{|c|}{$\longrightarrow(\mathrm{Mcal} / \mathrm{d}) \longrightarrow$} & \\
\hline Gross energy intake ${ }^{2}$ & 96.3 & 91.0 & 1.93 \\
\hline Feces & 32.3 & 31.1 & 0.85 \\
\hline Methane $^{4}$ & 4.3 & 3.5 & 0.09 \\
\hline Urine $^{3}$ & 3.5 & 3.9 & 0.09 \\
\hline Heat & 27.3 & 26.3 & 0.48 \\
\hline Retained & 28.9 & 26.2 & 1.17 \\
\hline Milk & 21.3 & 21.5 & 0.46 \\
\hline \multirow[t]{2}{*}{ Body $^{2}$} & 7.5 & 4.7 & 1.19 \\
\hline & \multicolumn{2}{|c|}{$\longrightarrow(\%$ of $\mathrm{GE})-$} & \\
\hline Feces & 33.4 & 33.8 & 0.58 \\
\hline Methane $^{4}$ & 4.43 & 3.79 & 0.07 \\
\hline Urine $^{4}$ & 3.69 & 4.28 & 0.08 \\
\hline Digestible & 66.6 & 66.2 & 0.58 \\
\hline Metabolizable & 58.5 & 58.2 & 0.59 \\
\hline
\end{tabular}

${ }^{1}$ Least square means.

${ }^{2}$ Means differ, $P<0.10$.

${ }^{3}$ Means differ, $P<0.05$.

${ }^{4}$ Means differ, $P<0.01$.

methane production were previously reported when feeding diets supplemented with fat from various sources (Van der Honing, 1980; Andrew et al., 1991). Differences in urinary energy loss appear to reflect the additional $49 \mathrm{~g} / \mathrm{d}$ of digestible $\mathrm{N}$ provided by the wet CDG diet. However, changes in urine and methane energy were small and offsetting. Metabolizable energy did not differ $(P>0.20)$ between the treatments.

Neither heat nor milk energy output (Mcal/d) were affected by diet $(P>0.15)$. In contrast, body energy balance (intake - (losses + milk)) was $2.8 \mathrm{Mcal} / \mathrm{d}$ greater for cows fed the control diet $(P<0.10)$.

Metabolizable energy was partitioned by multiple regression with the following model:

$$
\begin{aligned}
\mathrm{ME} \text { intake } & =\beta_{1} * \mathrm{BW}^{0.75}+\beta_{2} * \text { body energy retained } \\
& +\beta_{3} * \text { milk energy }+ \text { error }
\end{aligned}
$$

Only 4 of the body energy balances in the data set were negative, and milk energy was adjusted in those cases to reflect zero body energy change using a conversion of body energy to milk of 0.84 (Moe et al., 1970). This model resulted in biologically implausible coefficients. It was subsequently found that $\mathrm{BW}^{0.75}$ and body energy balance were moderately correlated. The reason for this is unknown. Rerunning the analysis without the $\beta_{1}$ $* \mathrm{BW}^{0.75}$ term resulted in estimates that did not differ by diet. The pooled regression terms were $1.17 \pm .08$, $1.51 \pm .13$, and $16.13 \pm 2.75$ for $\beta_{2}, \beta_{3}$, and the intercept, respectively. Partial efficiencies of ME use for milk (1/ $\left.\beta_{3}=\mathrm{K}_{1}\right)$ and body energy retention $\left(1 / \beta_{2}=\mathrm{K}_{\mathrm{r}}\right)$ were
Table 6. Energy content of control (C) and wet corn distillers grains (CDG) diets. ${ }^{1}$

\begin{tabular}{llcl}
\hline & \multicolumn{2}{c}{ Diets } \\
\cline { 2 - 3 } Item & $\mathrm{C}$ & Wet CDG & $\mathrm{SE}$ \\
\cline { 2 - 3 } & & $($ Mcal/kg DM) & \\
$\mathrm{GE}^{3}$ & 4.37 & 4.63 & 0.01 \\
$\mathrm{DE}^{3}$ & 2.91 & 3.06 & 0.03 \\
$\mathrm{ME}^{3}$ & 2.55 & 2.69 & 0.03 \\
$\mathrm{NEL}^{2}$ & 1.70 & 1.82 & 0.03 \\
\hline${ }^{1}$ Least square means. & & \\
${ }^{2}$ Means differ, $P<0.05$. & & \\
${ }^{3}$ Means differ, $P<0.01$. & &
\end{tabular}

0.66 and 0.85 , respectively. Division of the intercept by $\mathrm{BW}^{0.75}$ provided a maintenance $\mathrm{ME}$ requirement $\left(\mathbf{M E}_{\mathbf{m}}\right)$ estimate of $136.2 \mathrm{kcal} / \mathrm{BW}^{0.75}$ per day. These are similar to the $\mathrm{K}_{1}$ and $\mathrm{K}_{\mathrm{r}}$ reported by Chwalibog (1991) and the $\mathrm{K}_{1}$ estimate of Moe et al. (1972); however, $\mathrm{K}_{1}$ and $\mathrm{ME}_{\mathrm{m}}$ are considerably greater than those of the latter reference.

Energy estimates of diets are presented in Table 6 . Because the diets did not differ in efficiency of energy use, greater estimates for the wet CDG diet were a function of its greater $\mathrm{GE}$ content. The $\mathrm{NE}_{\mathrm{L}}$ values calculated with the partial efficiencies and $\mathrm{ME}_{\mathrm{m}}$ estimates from the current study were within $1 \%$ of those calculated when using the estimates of Moe et al. (1970). We assumed that digestible energy $(\mathbf{D E}), \mathrm{ME}$, and $\mathrm{NE}_{\mathrm{L}}$ for corn and soybean meal are: 3.53 and $3.70 \mathrm{Mcal}$ of DE/ $\mathrm{kg}$ of DM; 3.12 and $3.29 \mathrm{Mcal}$ of ME/kg of DM; and 1.84 and $1.94 \mathrm{Mcal}$ of $\mathrm{NE}_{\mathrm{L}} / \mathrm{kg}$ of $\mathrm{DM}$, respectively (NRC, 1989 ) in order to calculate values for CDG. Wet CDG estimates calculated by difference, and taking level of intake into account for $\mathrm{DE}$ and $\mathrm{ME}$ at $1 \times$ maintenance and $\mathrm{NE}_{\mathrm{L}}$ at $3 \times$ maintenance were $4.07,3.61$, and 2.21 $\mathrm{Mcal} / \mathrm{kg}$ of DM, repectively. These estimates were 15 to $20 \%$ greater than were reported for cracked corn and 7 to $11 \%$ more than reported for dried CDG by NRC (1989). Recalculation using the NRC (2001) values gave estimates of $\mathrm{DE}$ at $1 \times$ maintenance and $\mathrm{ME}$ and $\mathrm{NE}_{\mathrm{L}}$ at $3 \times$ maintenance for wet CDG of $4.09,3.36$, and 2.27 $\mathrm{Mcal} / \mathrm{kg}$ of DM, respectively, which were 10 to $15 \%$ higher than reported for dried CDG (NRC, 2001). It does not appear nutrient composition can explain differences with the latter. The wet CDG used in this study contained slightly less EE (8.5 vs. $10.0 \%$ ) and considerably more NDF (58.1 vs. $38.8 \%$ ) and ADF (23.4 vs. $19.7 \%$ ) than dried CDG (NRC, 2001). Differences of a similar magnitude, however, have been reported between wet and dried CDG with solubles (Ham et al., 1991) in growing beef cattle diets and attributed to the drying process. The results of our research do not imply that wet CDG contains more energy than does dried distillers 
grain because that comparison was not made. However, observations by our laboratory and by others indicate that most distillers grains, both wet and dried, available in recent years contain more protein and fat than are listed in publications such as NRC (2001).

\section{CONCLUSIONS}

Replacement of corn and soybean meal with wet CDG had only small effects on efficiency of diet energy utilization by lactating dairy cows. A greater $\mathrm{NE}_{\mathrm{L}}$ value of the wet CDG diet was a function of greater GE content resulting from the higher fat content of the wet CDG. Energy estimates for wet CDG were 7 to $11 \%$ greater than those reported for dried CDG by NRC (1989), and 10 to $15 \%$ greater than reported by NRC (2001).

\section{ACKNOWLEDGMENTS}

We thank the employees of the South Dakota State University Dairy Research Facility for care of the cows and for assistance in obtaining research data, and Valley Queen Cheese Factory, Milbank, SD, for milk analyses. This research was partially supported by funds from the South Dakota Corn Utilization Council.

\section{REFERENCES}

Andrew F. S. M., H. Tyrrell, C. K. Reynolds, and R. A. Erdman. 1991. Net energy for lactation of calcium salts of long-chain fatty acids for cows fed silage-based diets. J. Dairy Sci. 74:2588-2600.

Association of Official Analytical Chemists. 1990. Official Methods of Analysis. Vol. I and II. 15th ed. AOAC, Arlington, VA.

Brouwer, E. 1965. Report of subcommittee on constants and factors. Proc. 3rd Int. Symp. on Energy Met. EAAP Publ. No. 11:441.

Chwalibog, A. 1991. Partial efficiencies of energy deposition in milk. Proc. 12th Int. Symp. on Energy Met. EAAP Publ. No. 58:300.

Cochran, W. G., and G. M. Cox. 1957. Experimental Designs. 2nd ed. John Wiley \& Sons, Inc., New York, NY.

Dolge, K. L. 1988. What the feed industry wants from distillers grains. Proc. Distillers Feed Conf. 43:6-10.

Ham, G. A., R. A. Stock, T. J. Klopfenstein, E. M. Larson, D. H. Shain, and R. P. Huffman. 1994. Wet corn distillers byproducts compared with dried corn distillers grains with solubles as a source of protein and energy for ruminants. J. Anim. Sci. 72:3246-325.
Klopfenstein, T. J. 2001. Distillers grains for beef cattle. Pages 1-9 in Proc. National Corn Growers Association Ethanol Co-Products Workshop "DDGS: Issues to Opportunities," Nov. 7, 2001, Lincoln, NE.

Lahr, D. A., D. E. Otterby, D. G. Johnson, J. G. Linn, and R. G. Lundquist. 1983. Effects of moisture content of complete diets on feed intake and milk production of cows. J. Dairy Sci. 66:18911900.

Larson, E. M., R. A. Stock, T. J. Klopfenstein, M. H. Sindt, and R. P. Huffman. 1993. Feeding value of wet distillers byproducts for finishing ruminants. J. Anim. Sci. 71:2228-2235.

Moe, P. W., H. F. Tyrrell, and W. P. Flatt. 1970. Partial efficiency of energy use for maintenance, lactation, body gain, and gestation in the dairy cow. Proc. 5th Int. Symp. on Energy Met. EAAP Publ. No. 13:65.

Moe, P. W., W. P. Flatt, and H. F. Tyrrell. 1972. Net energy value of feeds for lactation. J. Dairy Sci. 55:945-958.

Murray, R. M., A. M. Bryant, and R. A. Lang. 1976. Rates of production of methane in the rumen and large intestine of sheep. Br. J. Nutr. 36:170.

National Research Council. 1989. Nutrient Requirements of Dairy Cattle. 6th rev. ed. Natl. Acad. Sci., Washington, DC.

National Research Council. 2001. Nutrient Requirements of Dairy Cattle. 7th rev. ed. Natl. Acad. Sci., Washington, DC.

Palmquist, D. L., and H. R. Conrad. 1982. Utilization of distillers dried grains plus solubles by dairy cows in early lactation. J. Dairy Sci. 65:1729-1733.

Palmquist, D. L., and T. C. Jenkins. 1980. Fat in lactation: Review. J. Dairy Sci. 63:1-14.

Robertson, J. B., and P. J. Van Soest. 1981. The detergent systems of analysis and its application to human foods. Pages 123-129 in Analysis of Dietary Fiber. W. P. T. James and O. Theander, ed. Marcel Dekker, New York, NY.

SAS User's Guide: Statistics, Version 6.08 ed. 1988. SAS Inst., Inc., Cary, NC.

Schingoethe, D. J. 2001. Using distillers grains in the dairy ration. Pages 10-17 in Proc. National Corn Growers Association Ethanol Co-Products Workshop "DDGS: Issues to Opportunities", Nov. 7, 2001, Lincoln, NE.

Schingoethe, D. J., M. J. Brouk, and C. P. Birkelo. 1999. Milk production and composition from cows fed wet corn distillers grains. J. Dairy Sci. 82:574-580.

Schingoethe, D. J., A. K. Clark, and H. H. Voelker. 1983. Wet corn distillers grains in lactating dairy cow rations. J. Dairy Sci. 66:345-349.

Shuey, S. A., C. P. Birkelo, and D. M. Marshall. 1993. The relationship of the maintenance energy requirement to heifer production efficiency. J. Anim. Sci. 71:2253-2259.

Van der Honing, Y. 1980. The utilization by high-yielding cows of energy from animal tallow or soya bean oil added to a diet rich in concentrate. Proc. 8th Int. Symp. on Energy Met. EAAP Publ. No. 26:315.

Van Soest, P. J., J. B. Robertson, and B. A. Lewis. 1991. Methods for dietary fiber, neutral detergent fiber, and nonstarch polysaccharides in relation to animal nutrition. J. Dairy Sci. 74:35833597 . 